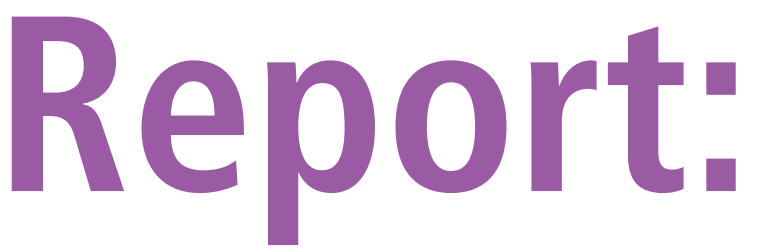

\title{
Infant and perinatal mortality
} by health areas in England and Wales, 2008

\section{Christopher Hill}

\section{Office for National Statistics}

\section{Key findings}

- There were 3,369 infant deaths (deaths under one year) registered in England and Wales in 2008, giving an infant mortality rate of 4.8 per thousand live births

- In 2008, there were 3,617 stillbirths and 1,763 deaths at ages under seven days registered in England and Wales, giving a total of 5,380 perinatal deaths

- The neonatal mortality rate (deaths under 28 days) decreased to 3.2 per thousand live births in 2008, from 3.3 in 2007. The postneonatal mortality rate (deaths between 28 days and one year) remained at 1.5 per thousand live births
This report gives statistics on infant deaths registered in 2008, and live births and stillbirths occurring in 2008, in England and Wales, for residents of each Government Office Region (GOR) and Strategic Health Authority (SHA) in England and Local Health Board (LHB) in Wales.

The figures in this report differ slightly from those presented in the 'Infant and perinatal mortality in England and Wales by social and biological factors, 2008' report published in this issue of Health Statistics Quarterly which are based on provisional numbers of infant deaths which occurred in England and Wales in 2008. The live births and stillbirths figures also differ slightly: this report used birth occurrences plus late registrations from the previous years, while the 'social and biological factors' report uses occurences only within each year.

The stillbirth rate decreased from 5.2 per thousand live births and stillbirths in 2007 to 5.1 per thousand live births and stillbirths in 2008. The perinatal

\section{Table 1}

Live births, stillbirths and infant deaths, 1978-2008

England and Wales

\begin{tabular}{|c|c|c|c|c|c|c|c|c|c|c|c|}
\hline \multirow[t]{2}{*}{ Year } & \multirow[b]{2}{*}{ Live births } & \multirow[b]{2}{*}{ Stillbirths ${ }^{1}$} & \multicolumn{4}{|c|}{ Number of deaths ${ }^{2}$} & \multirow[b]{2}{*}{$\begin{array}{l}\text { Stillbirth } \\
\text { rate }\end{array}$} & \multicolumn{4}{|c|}{ Mortality rates ${ }^{3}$} \\
\hline & & & $\begin{array}{c}\text { Early } \\
\text { neonatal }\end{array}$ & Neonatal & Postneonatal & Infant & & Perinatal & Neonatal & $\begin{array}{c}\text { Post- } \\
\text { neonatal }\end{array}$ & Infant \\
\hline \multicolumn{12}{|c|}{ Numbers } \\
\hline 1978 & 596,418 & 5,108 & 4,242 & 5,187 & 2,694 & 7,881 & 8.5 & 15.5 & 8.7 & 4.5 & 13.2 \\
\hline 1983 & 629,134 & 3,631 & 2,951 & 3,682 & 2,699 & 6,381 & 5.7 & 10.4 & 5.9 & 4.3 & 10.1 \\
\hline 1988 & 693,577 & 3,382 & 2,701 & 3,421 & 2,849 & 6,270 & 4.9 & 8.7 & 4.9 & 4.1 & 9.0 \\
\hline 1993 & 673,467 & 3,855 & 2,178 & 2,796 & 1,446 & 4,242 & 5.7 & 8.9 & 4.2 & 2.1 & 6.3 \\
\hline 1994 & 664,726 & 3,813 & 2,142 & 2,749 & 1,371 & 4,120 & 5.7 & 8.9 & 4.1 & 2.1 & 6.2 \\
\hline 1995 & 648,138 & 3,600 & 2,104 & 2,698 & 1,284 & 3,982 & 5.5 & 8.7 & 4.2 & 2.0 & 6.1 \\
\hline 1996 & 649,489 & 3,539 & 2,066 & 2,645 & 1,314 & 3,959 & 5.4 & 8.6 & 4.1 & 2.0 & 6.1 \\
\hline 1997 & 643,095 & 3,439 & 1,941 & 2,517 & 1,282 & 3,799 & 5.3 & 8.3 & 3.9 & 2.0 & 5.9 \\
\hline 1998 & 635,901 & 3,417 & 1,844 & 2,418 & 1,207 & 3,625 & 5.3 & 8.2 & 3.8 & 1.9 & 5.7 \\
\hline 1999 & 621,872 & 3,305 & 1,833 & 2,435 & 1,186 & 3,621 & 5.3 & 8.2 & 3.9 & 1.9 & 5.8 \\
\hline 2000 & 604,441 & 3,203 & 1,753 & 2,335 & 1,042 & 3,377 & 5.3 & 8.2 & 3.9 & 1.7 & 5.6 \\
\hline 2001 & 594,634 & 3,159 & 1,598 & 2,137 & 1,103 & 3,240 & 5.3 & 8.0 & 3.6 & 1.9 & 5.4 \\
\hline 2002 & 596,122 & 3,372 & 1,620 & 2,126 & 1,001 & 3,127 & 5.6 & 8.3 & 3.6 & 1.7 & 5.2 \\
\hline 2003 & 621,469 & 3,612 & 1,749 & 2,264 & 1,042 & 3,306 & 5.8 & 8.6 & 3.6 & 1.7 & 5.3 \\
\hline 2004 & 639,721 & 3,686 & 1,699 & 2,209 & 1,009 & 3,218 & 5.7 & 8.4 & 3.5 & 1.6 & 5.0 \\
\hline 2005 & 645,835 & 3,483 & 1,697 & 2,227 & 1,032 & 3,259 & 5.4 & 8.0 & 3.4 & 1.6 & 5.0 \\
\hline 2006 & 669,601 & 3,602 & 1,751 & 2,325 & 996 & 3,321 & 5.4 & 8.0 & 3.5 & 1.5 & 5.0 \\
\hline 2007 & 690,013 & 3,598 & 1,745 & 2,248 & 1,016 & 3,264 & 5.2 & 7.7 & 3.3 & 1.5 & 4.7 \\
\hline 2008 & 708,711 & 3,617 & 1,763 & 2,299 & 1,070 & 3,369 & 5.1 & 7.6 & 3.2 & 1.5 & 4.8 \\
\hline
\end{tabular}

1 See Background note 3.

2 Numbers of deaths shown are based on annual occurrences for years 1993 to 2007, and on annual registrations for all other years. 3 Stillbirths and perinatal deaths per 1,000 live births and stillbirths. Neonatal, postneonatal and infant deaths per 1,000 live births. 


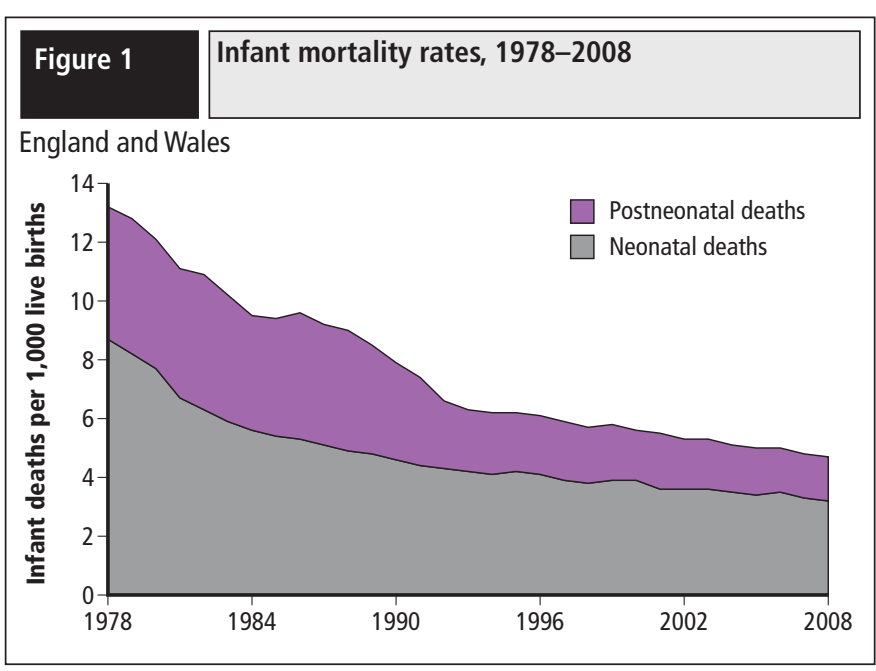

mortality rate also decreased from 7.7 per thousand live births and stillbirths in 2007 to 7.6 per thousand live births and stillbirths in 2008 (Table 1).

Figure 1 shows the infant mortality rate over the period 1978 to 2008 by age at death in the neonatal and postneonatal period. The infant mortality rate fell by 64 per cent over this period, while the neonatal and postneonatal mortality rates all fell by 63 and 67 per cent respectively. However, the rates of change were not constant over the period, change in the first half of the period being about twice that in the second half.

\section{Geographical variation in infant mortality}

There was considerable variation in the infant mortality rate across the health authorities. In 2008, West Midlands had the highest infant mortality rate among the SHAs in England at 6.5 deaths per thousand live births. South East Coast had the lowest at 3.8 deaths per thousand live births (Table 2). The highest infant mortality rate among the LHBs in Wales was 9.5 deaths per thousand live births in Torfaen (Table 3).

\section{Live births and birthweight}

There were 708,711 live births in England and Wales in 2008, compared with 690,013 in 2007 . This is a rise of 2.7 per cent and the seventh successive increase in the annual number of live births.

Low birthweight is one of the known risk factors for infant deaths. ${ }^{1}$ Table 2 shows the number of births and the proportions of low and very low birthweight babies for England and Wales and Strategic

\section{Table 2} Births, perinatal and infant mortality statistics, 2008

England and Wales, and Government Office Regions and Strategic Health Authorities in England

\begin{tabular}{|c|c|c|c|c|c|c|c|c|c|c|c|}
\hline \multirow[t]{3}{*}{ Area } & \multicolumn{5}{|c|}{ Numbers } & \multirow{2}{*}{\multicolumn{4}{|c|}{ Mortality rates ${ }^{1}$}} & \multirow{2}{*}{\multicolumn{2}{|c|}{$\begin{array}{l}\text { Percentage of live births } \\
\text { with a stated birthweight }\end{array}$}} \\
\hline & \multicolumn{2}{|c|}{ Births } & \multicolumn{3}{|c|}{ Deaths } & & & & & & \\
\hline & Live births & Stillbirths & $\begin{array}{c}\text { Early } \\
\text { neonatal }\end{array}$ & Neonatal & Infant & Perinatal & Neonatal & $\begin{array}{c}\text { Post- } \\
\text { neonatal }\end{array}$ & Infant & $\begin{array}{l}\text { Under } \\
1,500 \mathrm{~g}\end{array}$ & $\begin{array}{l}\text { Under } \\
2,500 \mathrm{~g}\end{array}$ \\
\hline England and Wales ${ }^{2}$ & 708,711 & 3,617 & 1,763 & 2,299 & 3,369 & 7.6 & 3.2 & 1.5 & 4.8 & 1.2 & 7.2 \\
\hline England & 672,809 & 3,427 & 1,679 & 2,177 & 3,184 & 7.6 & 3.2 & 1.5 & 4.7 & 1.2 & 7.2 \\
\hline North East & 30,217 & 179 & 68 & 97 & 127 & 8.1 & 3.2 & 1.0 & 4.2 & 1.3 & 7.6 \\
\hline North East & 30,217 & 179 & 68 & 97 & 127 & 8.1 & 3.2 & 1.0 & 4.2 & 1.3 & 7.6 \\
\hline North West & 88,167 & 450 & 239 & 307 & 455 & 7.8 & 3.5 & 1.7 & 5.2 & 1.2 & 7.3 \\
\hline North West & 88,167 & 450 & 239 & 307 & 455 & 7.8 & 3.5 & 1.7 & 5.2 & 1.2 & 7.3 \\
\hline Yorkshire and The Humber & 66,353 & 371 & 159 & 222 & 357 & 7.9 & 3.3 & 2.0 & 5.4 & 1.2 & 7.4 \\
\hline Yorkshire and the Humber & 66,353 & 371 & 159 & 222 & 357 & 7.9 & 3.3 & 2.0 & 5.4 & 1.2 & 7.4 \\
\hline East Midlands & 54,192 & 255 & 150 & 190 & 266 & 7.4 & 3.5 & 1.4 & 4.9 & 1.2 & 7.1 \\
\hline East Midlands & 54,192 & 255 & 150 & 190 & 266 & 7.4 & 3.5 & 1.4 & 4.9 & 1.2 & 7.1 \\
\hline West Midlands & 71,726 & 403 & 269 & 329 & 469 & 9.3 & 4.6 & 2.0 & 6.5 & 1.3 & 8.5 \\
\hline West Midlands & 71,726 & 403 & 269 & 329 & 469 & 9.3 & 4.6 & 2.0 & 6.5 & 1.3 & 8.5 \\
\hline East & 71,738 & 304 & 161 & 214 & 314 & 6.5 & 3.0 & 1.4 & 4.4 & 1.2 & 6.5 \\
\hline East of England & 71,738 & 304 & 161 & 214 & 314 & 6.5 & 3.0 & 1.4 & 4.4 & 1.2 & 6.5 \\
\hline London & 127,651 & 730 & 276 & 361 & 545 & 7.8 & 2.8 & 1.4 & 4.3 & 1.4 & 7.6 \\
\hline London & 127,651 & 730 & 276 & 361 & 545 & 7.8 & 2.8 & 1.4 & 4.3 & 1.4 & 7.6 \\
\hline South East & 104,023 & 471 & 230 & 292 & 417 & 6.7 & 2.8 & 1.2 & 4.0 & 1.1 & 6.3 \\
\hline $\begin{array}{l}\text { South East Coast } \\
\text { South Central }\end{array}$ & $\begin{array}{l}51,565 \\
52,458\end{array}$ & $\begin{array}{l}235 \\
236\end{array}$ & $\begin{array}{l}109 \\
121\end{array}$ & $\begin{array}{l}138 \\
154\end{array}$ & $\begin{array}{l}197 \\
220\end{array}$ & $\begin{array}{l}6.6 \\
6.8\end{array}$ & $\begin{array}{l}2.7 \\
2.9\end{array}$ & $\begin{array}{l}1.1 \\
1.3\end{array}$ & $\begin{array}{l}3.8 \\
4.2\end{array}$ & $\begin{array}{l}1.1 \\
1.1\end{array}$ & $\begin{array}{l}6.2 \\
6.5\end{array}$ \\
\hline South West & 58,742 & 264 & 127 & 165 & 234 & 6.6 & 2.8 & 1.2 & 4.0 & 1.0 & 6.2 \\
\hline South West & 58,742 & 264 & 127 & 165 & 234 & 6.6 & 2.8 & 1.2 & 4.0 & 1.0 & 6.2 \\
\hline Wales & 35,650 & 165 & 76 & 108 & 147 & 6.7 & 3.0 & 1.1 & 4.1 & 1.8 & 7.8 \\
\hline Usual residence outside England and Wales & 252 & 25 & 8 & 14 & 38 & : & : & $:$ & : & $:$ & : \\
\hline
\end{tabular}

1 Perinatal deaths per 1,000 live births and stillbirths. Neonatal, postneonatal and infant deaths per 1,000 live births.

2 Including births and deaths to persons normally resident outside England and Wales.

: not applicable 
Local Health Boards in Wales

\begin{tabular}{|c|c|c|c|c|c|c|c|c|c|}
\hline \multirow[t]{2}{*}{ Area } & \multicolumn{4}{|c|}{ Numbers } & \multicolumn{3}{|c|}{ Mortality rates ${ }^{1}$} & \multicolumn{2}{|c|}{$\begin{array}{c}\text { Percentage of live births with a } \\
\text { stated birthweight }\end{array}$} \\
\hline & Live births & $\begin{array}{l}\text { Perinatal } \\
\text { deaths }\end{array}$ & $\begin{array}{l}\text { Neonatal } \\
\text { deaths }\end{array}$ & $\begin{array}{l}\text { Infant } \\
\text { deaths }\end{array}$ & Perinatal & Neonatal & Infant & $\begin{array}{l}\text { Under } \\
1,500 \mathrm{~g}\end{array}$ & $\begin{array}{l}\text { Under } \\
2,500 \mathrm{~g}\end{array}$ \\
\hline Wales & 35,650 & 241 & 108 & 147 & 6.7 & 3.0 & 4.1 & 1.8 & 7.8 \\
\hline Anglesey & 780 & * & 2 & 4 & * & 2.6 & 5.1 & 2.6 & 8.2 \\
\hline Gwynedd & 1,276 & 13 & 4 & 5 & 10.1 & 3.1 & 3.9 & 2.6 & 7.5 \\
\hline Conwy & 1,163 & 7 & 5 & 6 & 6.0 & 4.3 & 5.2 & 2.0 & 7.9 \\
\hline Denbighshire & 1,076 & 6 & 4 & 5 & 5.6 & 3.7 & 4.6 & 1.8 & 7.3 \\
\hline Flintshire & 1,743 & 7 & 6 & 7 & 4.0 & 3.4 & 4.0 & 1.6 & 6.8 \\
\hline Wrexham & 1,793 & 8 & 4 & 4 & 4.4 & 2.2 & 2.2 & 1.4 & 8.0 \\
\hline Powys Teaching & 1,280 & * & - & 2 & * & - & 1.6 & 0.6 & 7.8 \\
\hline Ceredigion & 603 & 5 & 1 & 1 & 8.2 & 1.7 & 1.7 & 0.8 & 4.5 \\
\hline Pembrokeshire & 1,251 & 10 & 5 & 5 & 8.0 & 4.0 & 4.0 & 1.5 & 7.0 \\
\hline Carmarthenshire & 1,971 & 11 & 3 & 5 & 5.6 & 1.5 & 2.5 & 1.0 & 6.0 \\
\hline Swansea & 2,732 & 16 & 7 & 11 & 5.8 & 2.6 & 4.0 & 1.0 & 5.9 \\
\hline Neath Port Talbot & 1,551 & 9 & 5 & 7 & 5.8 & 3.2 & 4.5 & 3.9 & 9.7 \\
\hline Bridgend & 1,630 & 8 & 2 & 2 & 4.9 & 1.2 & 1.2 & 7.3 & 13.3 \\
\hline Vale of Glamorgan & 1,482 & 16 & 6 & 10 & 10.7 & 4.0 & 6.7 & 2.6 & 8.4 \\
\hline Cardiff & 4,566 & 41 & 17 & 20 & 8.9 & 3.7 & 4.4 & 1.0 & 7.1 \\
\hline Rhondda Cynon Taff Teaching & 2,908 & 18 & 4 & 7 & 6.2 & 1.4 & 2.4 & 1.3 & 8.2 \\
\hline Merthyr Tydfil & 781 & 8 & 5 & 5 & 10.2 & 6.4 & 6.4 & 2.2 & 8.2 \\
\hline Caerphilly Teaching & 2,223 & 13 & 7 & 11 & 5.8 & 3.1 & 4.9 & 1.8 & 7.7 \\
\hline Blaenau Gwent & 867 & 5 & 4 & 6 & 5.8 & 4.6 & 6.9 & 1.4 & 8.7 \\
\hline Torfaen & 1,056 & 10 & 7 & 10 & 9.4 & 6.6 & 9.5 & 2.3 & 8.3 \\
\hline Monmouthshire & 919 & 6 & 3 & 3 & 6.5 & 3.3 & 3.3 & 1.5 & 6.4 \\
\hline Newport & 1,999 & 16 & 7 & 11 & 8.0 & 3.5 & 5.5 & 1.5 & 8.4 \\
\hline
\end{tabular}

1 Perinatal deaths per 1,000 live births and stillbirths. Neonatal and infant deaths per 1,000 live births.

* For perinatal deaths, some counts and rates have been suppressed to protect confidentiality.

Note: Mortality rates calculated from fewer than 20 deaths are distinguished by italic type as a warning that their reliability as a measure may be affected by the small number of events.

Health Authorities in England in 2008. Of those live births with a stated birthweight in England and Wales, 7.2 per cent had a low birthweight (under 2,500 grams) and 1.2 per cent had a very low birthweight (under 1,500 grams). These percentages are unchanged from 2007.

Among the SHAs in England, London had the highest proportion of very low birthweight babies with 1.4 per cent weighing under $1,500 \mathrm{~g}$ and West Midlands had the highest proportion of low birthweight babies with 8.5 per cent of babies weighing under 2,500g. The SHAs with the lowest proportion of low birthweight babies were South East Coast and South West with 6.2 per cent. South West also had the lowest proportion of very low birthweight babies with 1.0 per cent.

Table 3 shows that among the Local Health Boards of Wales in 2008, the percentage of low birthweight babies was highest in Bridgend (13 per cent) and lowest in Ceredigion ( 4.5 per cent). The proportion of very low birthweight babies ranged from 0.6 per cent in Powys Teaching, to 7.3 per cent in Bridgend.

\section{Box one}

\section{Definitions used in this report:}

Early neonatal death: deaths at ages under seven days

Perinatal deaths: stillbirths plus deaths at ages under seven days

Neonatal deaths: deaths at age under 28 days

Postneonatal deaths: deaths between 28 days and one year

Infant deaths: deaths under one year

\section{Background notes}

1. Statistics: although the live birth numbers are based on births occurring in 2008, the mortality data here are based on deaths registered in 2008. Additionally, in Table 1 numbers of deaths for 1993 to 2007 are based on occurrences in these years, while numbers for years prior to 1993 are based on registrations. The mortality rates in Table 3 which have been calculated from fewer than 20 deaths are distinguished by italic type as a warning to the user that their reliability may be affected by the small number of events. Areal statistics in this report are derived from the usual residence at the time of birth or death. If the usual residence was outside England and Wales, these events are included in the aggregate for 'England and Wales', but excluded from the figures for individual health areas and GORs. In Table 2, rates and percentages have been excluded where the usual residence was outside England and Wales.

2. Recording of birthweight: since 1975 the Office for National Statistics (formerly the Office of Population, Censuses and Surveys) has obtained the birthweight of a baby from information provided to the Registrar of Births and Deaths by the local health services. Since 2007, with the introduction of the Registration Online system (RON) for registering births and deaths in some districts, ONS has obtained the birthweight for those babies from the NHS Numbers for Babies record. In 2008, birthweight was recorded for 99.2 per cent of all live births and 65.8 per cent of live birth registrations were recorded on RON.

3. Legal definition of stillbirths: on 1 October 1992 the legal definition of a stillbirth was changed from a baby born dead after 28 or more weeks completed gestation to one born dead after 24 or more weeks completed 
gestation. This means that perinatal and stillbirth data for 2008 can only be compared with data from 1993 onwards.

4. General: more details on the above, and on other aspects of stillbirth and infant mortality data, can be found in the ONS annual reference volume Mortality statistics: childhood, infant and perinatal 2007, Series DH3 no. 40, published in March 2009. ${ }^{2}$

\section{References}

1. Office for National Statistics (2008) 'Report: Infant and perinatal mortality by social and biological factors, 2007', Health Statistics Quarterly 40, 61-65. Available on the Office for National Statistics website at: www.statistics.gov.uk/statbase/Product.asp?vlnk=6725

2. Office for National Statistics (2009) Mortality statistics: childhood, infant and perinatal 2007, Series DH3 no. 40. Available on the Office for National Statistics website at:

www.statistics.gov.uk/statbase/Product.asp?vlnk=6305 